\title{
EFFICACY OF EGG SHELL-CALCIUM OXIDE AS NATURAL INACTIVATOR TO RABIES VIRUS FOR PREPARING RABIES VACCINE
}

\author{
SHENDY, M.B.; A.F. SOLIMAN; HEMMAT S.AL-EMAM and ATTYAT M.KOTB
}

Veterinary Serum and Vaccine Research Institute, Abbasia, Cairo

P.O.Box:131- Fax: (202) 23428321 svri@id

(Manuscript received 17 September 2017)

\begin{abstract}

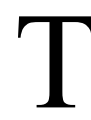
his work was conducted to study the inactivation dynamics of Rabies Virus (RV) by calcinated eggshell calcium oxide ( $\mathrm{CaO})$ in comparison with Binary Ethyleneimine (BEI). Calcinated eggshell, of which the main component is calcium oxide, was evaluated in the form of powder as inactivator to rabies virus. The calcination process yielded calcium oxide with a purity of $97.92 \%$ $w / w$. The results of $X-R$ diffraction showed that the optimum calcination conditions for preparation of $\mathrm{CaO}$ from chicken eggshell is $900^{\circ} \mathrm{C}$ for 1 hour with peak $2 \theta\left(2-\right.$ Theta) at $32.3^{\circ}, 37.4^{\circ}, 54.0^{\circ}$, $64.3^{\circ}$ and $67.5^{\circ}$. Complete virus inactivation was obtained with BEI ( $3 \%$ of $0.001 \mathrm{M})$ after incubation for 3 hours. On the other hand, $10 \%$ Egg-CaO solution inactivated RV within 15 minutes. The safety and potency of $\mathrm{CaO}$ prepared inactivated rabies vaccines were evaluated in three groups of puppies. The inactivated rabies vaccine produced sufficient level of antibodies as measured by serum neutralization test (SNT) and was protected when challenged in mice. The obtained results revealed that no residual infectious virus was detected in Egg-CaO inactivated rabies vaccine that proved to be safe and effective as compared the same virus that inactivated with the classical inactivating agent.

Key words: Rabies vaccine, calcinated eggshell (Egg-CaO), binary ethylenimine, inactivators, XR- diffraction.
\end{abstract}

\section{INTRODUCTION}

Rabies virus causes a fatal illness characterized by encephalopathy and generalized paresis (1). It remains a significant threat to human and animal health throughout the world (2\&3). Domestic dogs play a main role in rabies transmission which accounts for more than $95 \%$ of human rabies cases (4). Consequently, the vaccination of dogs against rabies is believed to be one of the most effective approaches for the control of the disease and its transmission to humans (5). Research has shown that the vaccination of $70 \%$ of dogs should be sufficient to prevent epidemics and eliminate endemic rabies infections (6). Vaccines can be classified as live attenuated and inactivated. Currently, the recommended inactivating agent for this virus is beta propiolactone (BPL), which is a very expensive chemical and potentially carcinogenic (7). Other chemicals like formaldehyde and phenol not only inactivate the virus but also 
adversely affect its antigenicity. Binary ethyleneimine (BEI), member of a group of alkylating substances "aziridines" reacts very little with proteins and therefore does not alter the antigenic components of the virus. BEI has an inactivation reaction that is more specific for the nucleic acid and it produces antigenically superior vaccine (8). Binary ethyleneimine (BEI) is very hazardous since it attacks nucleic acids and proteins. Thus, the current study is a trail to find an alternative inactivating agents which are not expensive, non-toxic and easily available. Disinfection effect of slaked lime is maintained for a long period if it is dry powder, but if it turns wet by rain, it becomes hardened (9). In addition, it was reported that when slaked lime was combined with carbon dioxide in the air or rain water, it became calcium carbonate $(\mathrm{CaCO} 3)$ and the $\mathrm{pH}$ got lowered, bringing about the disappearance of disinfection effect (10). The egg and egg derivative consumption produce a great amount of residual shells which pose an environmental pollution as a result of microbial action. Chicken eggshell is household waste and its utilization is still relatively small. Eggshell containing calcium carbonate (94\%), calcium phosphate (1\%), organic compounds (4\%), and magnesium carbonate (1\%) (11). Wei, et al., illustrated that the high contents of calcium in eggshells can be converted as a $\mathrm{CaO}$ catalyst by calcinations process at temperature $900^{\circ} \mathrm{C}$ for 1 hour, where the reaction takes place as exothermic reaction and the decomposition of eggshell to produce $\mathrm{CaO}$ as a catalyst was run at various temperatures $600,700,800,900$, and $1000^{\circ} \mathrm{C}$, and then the characterization of $\mathrm{CaO}$ had done by X-R diffraction (12). The catalytic activities of calcium oxide obtained from natural sources (eggshell) were characterized and evaluated in the transesterification of vegetable oil. These catalysts are mainly composed of calcium carbonate, which is partially converted into $\mathrm{CaO}$ after calcination $\left(900^{\circ} \mathrm{C}\right.$ for 2 hours). Thammakarn, et al., reported that scallop shell powder solution at pH 12.3 did not inactivate avian influenza AIV (H7N1), however, at $\mathrm{pH} 13.0$ it did. Therefore, aqueous solution above $\mathrm{pH} 12.5$ seems to be able to inactivate the influenza viruses (13). The catalysts have some advantages, such as abundant occurrence, low cost, porous structure, and non-toxic (14).

The current study aims to prepare and evaluate the efficacy of a prepared inactivated rabies vaccine using eggshell calcium oxide $(\mathrm{CaO})$ as inactivator in comparison with the classical inactivator binary ethylenimine (BEI) and assayed them in puppies.

\section{MATERIALS AND METHODS}

\section{Rabies virus:}

BHK-21 cell culture adapted Evelyn Rokitincki Abelesth strain of rabies virus (ERA) of a titer $10^{7} \mathrm{TCID}_{50} / \mathrm{ml}$, was supplied by the Department of Pet Animal Vaccine 
Research, Veterinary Serum and Vaccine Research Institute (VSVRI). Abbasia, Cairo, and used for vaccine preparation and serum neutralization test (SNT).

\section{Baby Hamster Kidney cell (BHK-21):}

BHK-21 cell culture was used for preparation of rabies virus suspension and detection of rabies virus antibodies in vaccinated puppies by serum neutralization test (SNT).

\section{Challenge virus strain (CVS):}

It is a fixed virus strain derived from the original Pasteur strain. It was propagated and fixed in mice brain. CVS was supplied kindly by Pasteur Institute, Paris, in a lyophilized form with a titer of $10^{5} \mathrm{MILD} \mathrm{D}_{50} / \mathrm{ml}$ and used in the test of the National Institute of Health (NIH) during evaluation of the prepared vaccine formulae.

\section{Chicken eggshells:}

Raw chicken eggshells were collected and washed with tap water until the egg white was completely removed and dried at room temperature. After that the eggshells were broken into small pieces and crushed in a porcelain mortar into a fine powder, and kept in desiccators at a room temperature.

\section{5. inactivators:}

\subsection{Calcinated eggshell $(\mathrm{CaO})$ powder:}

The eggshell was rinsed several times with deionized water. Then, the eggshell was dried at $100^{\circ} \mathrm{C}$ in the dry oven. The dried eggshell was crushed and sieved to pass 60 meshes. An amount of $200 \mathrm{~g}$ of the chicken eggshell was calcinated in a laboratory muffle furnace in Central Metallurgical Research and Development Institute (CMRDI). Tibin, Helwan, Cairo. The samples were calcined in an alumina crucible for 1, 3, and 5 hours at a heating rate of $10^{\circ} \mathrm{C} / \mathrm{min}$, at temperatures between 300 to $900^{\circ} \mathrm{C}$ for 1 , 3and 5 hours. After calcination process completed a cold solid is obtained and down in air for a period of 20 minutes to avoid the hydrolysis, and stored in a desiccator for 24 hours. The structure of metal oxide was characterized using X-ray diffraction (XRD). Calcinated eggshell powder, was prepared in the suspensions of $3 \%, 5 \%$ and $10 \%(\mathrm{w} / \mathrm{v})$ of Egg$\mathrm{CaO}$ in redistilled water $\left(\mathrm{dw}_{2}\right)$ and then centrifuged at $12.000 \mathrm{xg}$ for 3 minutes, and the resulted supernatants were used as Egg-CaO solutions with $\mathrm{pH}$ at 12.7 (12).

\subsection{Binary Ethyleneimine (BEI):}

The inactivation process was carried out (8), where BEI was added at $37^{\circ} \mathrm{C}$ to the viral suspension as $3 \%$ concentration of $0.01 \mathrm{M}$. The mixture was stirred continuously at $37^{\circ} \mathrm{C}$ for 3.5 hours. Inactivation process was stopped by addition of cold sodium thiosulphate with a final concentration of $2 \%$. 


\section{Adjuvant:}

\subsection{Aluminum hydroxide gel $(20 \%)$ :}

Rehydra Gel $\circledast$ LV. Aluminum hydroxide of low viscosity, was supplied by Chemtrade, New Jersey 07922 . USA. It was added as $20 \%$ to inactivated rabies virus suspension as adjuvant (15 \&16).

\section{Vaccine Preparation:}

In order to prepare the virus suspension, it was preferable to replicate the virus at a multiplicity of infection (M.O.I), rate of $2: 1$ of virus/BHK-21 cells (16). The virus suspension was divided into 2 parts. The first part was divided into 3 portions to be inactivated with 3\%, 5\% and 10\% Egg-CaO (4:1), and incubated for indicated time (3 min to $1 \mathrm{hr}$ ) at room temperature and then neutralized with $1 \mathrm{M}$ HEPES (4-(2hydroxyethyl)-1-piperazineethanesulfonic acid) ( $\mathrm{pH}$ 7.2).The second part was inactivated with BEI. Aluminum hydroxide gel was added to the inactivated virus suspension as adjuvant.

\section{Reference rabies vaccine:}

Delvac rabies vaccine was obtained from Mycofarm UK Limited Science Park, Milton Road; Cambridge CB44FR. It was used as a reference vaccine in application of NIH test. The vaccine is containing cloned rabies virus strain RIV/PTA/78/BHK clone 8.

\section{Calculation of Reduction Factor (RF):}

Inactivation efficacy against rabies virus was determined using reduction factor (RF), which is calculated by the following equation: $R F=\log _{10}$ (amount of untreated intact virus $/ \mathrm{ml}$ )- $\log _{10}$ (amount of treated virus with $\mathrm{Egg}-\mathrm{CaO} / \mathrm{ml}$ ). Inactivation was considered to be satisfied when RF was $\geq 3$ (13).

\section{Experimental animals:}

\subsection{Dogs:}

Twenty native breed puppies of about 3-4 months age were used in the present work and proved to be seronegative to rabies antibodies as screened by serum neutralization test (SNT). They were apparently health free from external and internal parasites and housed under hygienic measures in separate kennels receiving balanced diet and adequate water.

\subsection{Mice:}

Two hundred Albino Swiss mice (18-22g) 3-4 weeks old were supplied by the Department of Pet Animal Vaccine Research, Veterinary Serum and Vaccine Research Institute, Abbasia, Cairo. These mice were used in the quality control tests of prepared rabies vaccine formulae, through application of the test of National Institute of Health (NIH). All challenged mice were observed daily for two weeks for disease signs and survival. 


\section{Evaluation of prepared inactivated rabies vaccine:}

\subsection{Sterility test:}

The inactivated virus was inoculated into blood agar and Sabouraud's dextrose agar to ensure the absence of bacterial and mycotic contamination, respectively.

\subsection{Safety test:}

In cell line: The inactivated virus suspensions were inoculated into BHK-21 cell monolayers to confirm total complete inactivation

In Mice: inoculated with inactivated rabies virus intracerebrally (I / C).

In dogs: Five puppies were injected with double doses of each prepared vaccines, $\mathrm{S} / \mathrm{C}$ in different sites and observed for 15 days for development of any clinical signs or local reaction.

\subsection{Potency:}

The potency of the prepared vaccine formulae was evaluated using National Institute of Health (NIH) test. The mice were divided into four groups (50 mice / each) and injected intraprotenial with fivefold dilutions (1/5 to 1/50). Two doses of each vaccine were given to each mice group two weeks apart. Mice were challenged with CVS virus strain at three weeks after the last immunization, using a dose of $0.03 \mathrm{ml}$, intracerebrally. All challenged mice were observed daily for two weeks for disease signs and survival. NIH was carried out according to (17), using the volumetric method to evaluate the antigenic value as following equation:

$$
\text { Antigenic value }(A V)=\frac{E D_{50} \text { of reference vaccine }}{E D_{50} \text { of test vaccine }}
$$

\section{Animal immunization:}

Puppies were divided into three groups (5 animals / each) and subcutaneously injected as follow:

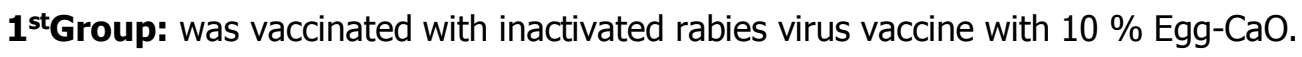

$2^{\text {nd }}$ Group: was vaccinated with inactivated rabies virus vaccine with BEI.

$3^{\text {rd }}$ Group: unvaccinated as animal control.

Blood was collected from the vaccinated and non-vaccinated puppies weekly for 4 weeks post vaccination then every month up to 4 months (16 weeks). Serum was separated to estimate rabies serum neutralizing antibodies.

\section{Serum neutralization test (SNT):}

It was carried out (18), and used to follow up the induced rabies antibodies in vaccinated animals. The antibody titer was calculated as the reciprocal of the final serum dilution which neutralized and inhibited the CPE of 100 TCID $_{50}$ of rabies virus (19). 


\section{RESULTS AND DISCUSSION}

Table 1. XRD data of $\mathrm{CaO}$ and $\mathrm{Ca}(\mathrm{OH})_{2}$ from chicken eggshell calcinated at various temperatures

\begin{tabular}{|c|c|c|c|c|c|}
\hline Caption & Legend & Angle & d value & Intensity & Intensity \% \\
\hline & & 2-Theta $(2 \theta)$ & Angstrom & Count & $\%$ \\
\hline $\mathrm{d}=4.90294$ & $\mathrm{Ca}(\mathrm{oH}) 2$ & 18.078 & 4.90294 & 31.7 & 6.7 \\
\hline $\mathrm{d}=3.09716$ & $\mathrm{Ca}(\mathrm{oH}) 2$ & 28.803 & 3.09716 & 22.7 & 4.8 \\
\hline $\mathrm{d}=2.76700$ & $\mathrm{CaO}$ & 32.328 & 2.767 & 175 & 37.1 \\
\hline $\mathrm{d}=2.61590$ & $\mathrm{Ca}(\mathrm{oH}) 2$ & 34.251 & 2.6159 & 50.8 & 10.8 \\
\hline $\mathrm{d}=2.39758$ & $\mathrm{CaO}$ & 37.481 & 2.39758 & 471 & 100 \\
\hline $\mathrm{d}=1.92488$ & $\mathrm{Ca}(\mathrm{oH}) 2$ & 47.179 & 1.92488 & 20.7 & 4.4 \\
\hline $\mathrm{d}=1.79209$ & $\mathrm{Ca}(\mathrm{oH}) 2$ & 50.914 & 1.79209 & 19.5 & 4.1 \\
\hline $\mathrm{d}=1.69619$ & $\mathrm{CaO}$ & 54.019 & 1.69619 & 195 & 41.4 \\
\hline $\mathrm{d}=1.44740$ & $\mathrm{CaO}$ & 64.308 & 1.4474 & 57.8 & 12.3 \\
\hline $\mathrm{d}=1.38585$ & $\mathrm{CaO}$ & 67.536 & 1.38585 & 52.8 & 11.2 \\
\hline
\end{tabular}

Started XRD: 4.00 - End: $70.000-S t e p ~ 0.020^{\circ}$ - step time: $0.4 \mathrm{~s}$ - Temp: $25^{\circ} \mathrm{C}$ (Room) Time started: $0 \mathrm{~s}-2$ Theta: 4.000 - Theta: 2.00

Portlandite, syn $-\mathrm{Ca}(\mathrm{OH})_{2}-\mathrm{y}: 10.42 \%-\mathrm{dx}$ by: $1-\mathrm{wl}$

Lime - CaO -y: $97.92 \%$

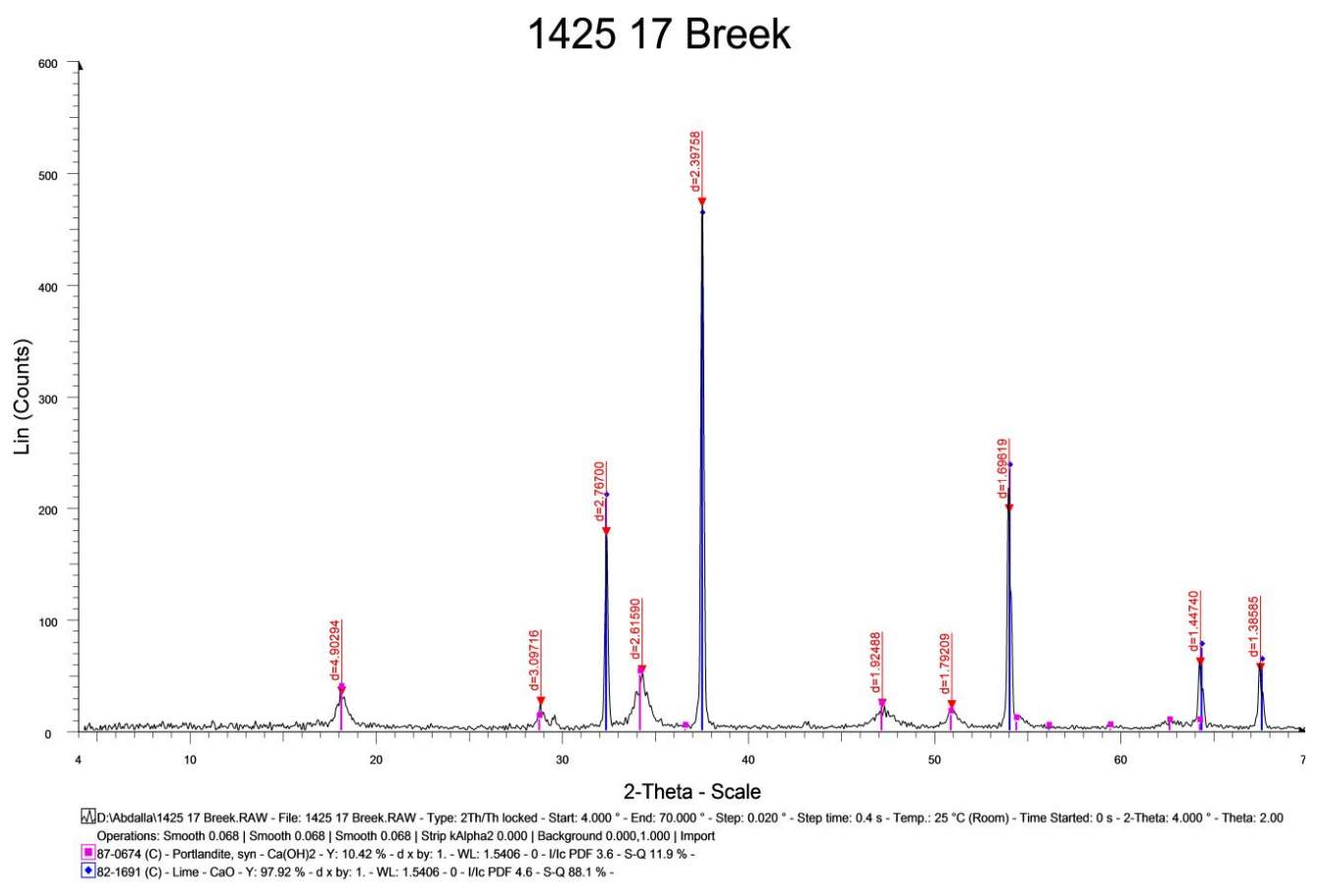

Fig. 1. XRD peak patterns and the phase transformation of chicken eggshells calcinated from $300^{\circ} \mathrm{C}$ to $900^{\circ} \mathrm{C}$ for $1 \mathrm{~h}$. 
Table 2. Inactivation of rabies virus using calcinated eggshell $(\mathrm{CaO})$ at $25^{\circ} \mathrm{C}$

\begin{tabular}{|c|c|c|c|}
\hline \multirow{2}{*}{$\begin{array}{c}\text { Periods of virus } \\
\text { inactivation process/ } \\
\text { min. }\end{array}$} & \multicolumn{3}{|c|}{ Virus titer $\left(\log _{10} \mathrm{TCID}_{50} / \mathrm{ml}\right)$ with different concentrations of Egg-CaO } \\
solutions $(\mathrm{pH} 7.2)$
\end{tabular}

Reduction factor $(\mathrm{RF})=\log _{10}$ (amount of untreated intact virus $/ \mathrm{ml}$ ) $-\log _{10}$ (amount of treated virus with Egg- $\mathrm{CaO} / \mathrm{ml}$ ).Inactivation was considered to be satisfied when RF was $\geq 3$.

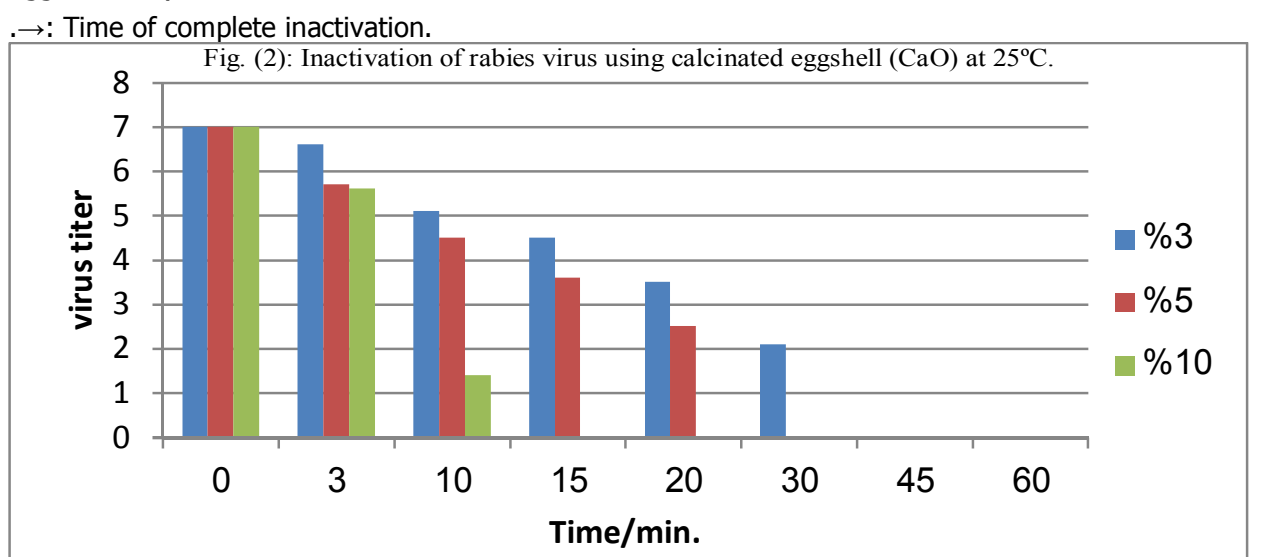

Table 3. Inactivation of rabies virus using Binary Ethyleneimine (BEI) at $37^{\circ} \mathrm{C}$

\begin{tabular}{|c|c|c|c|}
\hline \multirow{2}{*}{$\begin{array}{c}\text { Periods of virus } \\
\text { inactivation process/ } \\
\text { hours }\end{array}$} & \multicolumn{3}{|c|}{ Virus titer $\left(\right.$ Log $\left._{10} \mathrm{TCID}_{50} / \mathrm{ml}\right)$ with different molarities of BEI } \\
\cline { 2 - 4 } & $(0.001)$ & $(0.002)$ & $(0.003)$ \\
\hline Pre-inactivation & 7 & 7 & 7 \\
\hline 1 & 6.7 & 6.6 & 4.8 \\
\hline 2 & 6.5 & 6.2 & 3.5 \\
\hline$\rightarrow 3$ & 6.0 & 5.4 & 0.0 \\
\hline 4 & 5.7 & 4.6 & 0.0 \\
\hline 5 & 4.8 & 0.0 & 0.0 \\
\hline 6 & 4.7 & 0.0 & 0.0 \\
\hline 7 & 0.0 & 0.0 & $>3.5$ \\
\hline RF & $>2.3$ & $>2.4$ & 0.0 \\
\hline
\end{tabular}

Reduction factor $(R F)=\log _{10}$ (amount of untreated intact virus/ml) - $\log _{10}$ (amount of treated virus with $\mathrm{BEI} / \mathrm{ml}$ ). Inactivation was considered to be satisfied when $\mathrm{RF}$ was $\geq 3$

$\rightarrow$ : Time of complete inactivation. 


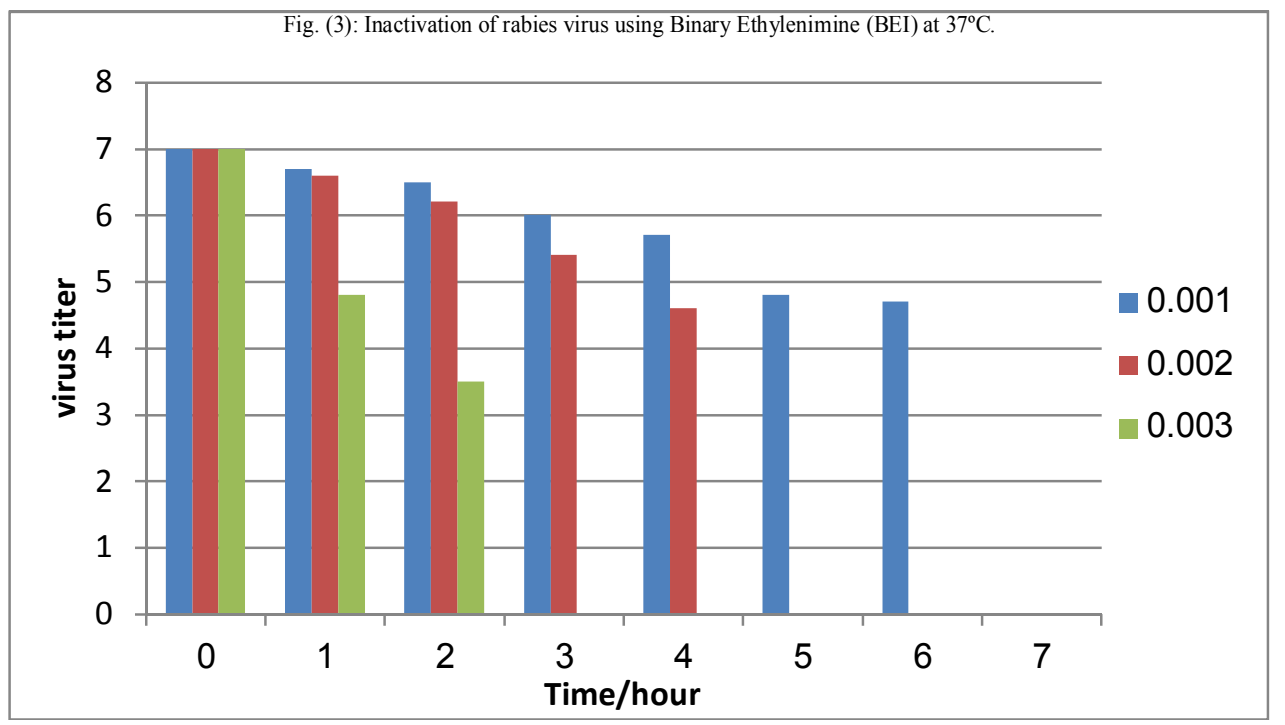

Table 4. Antigenic values of the prepared rabies vaccine formulae

\begin{tabular}{|c|c|c|c|}
\hline $\begin{array}{c}\text { Tested rabies vaccine } \\
\text { formulae }\end{array}$ & Inactivators & Adjuvant & Antigenic value \\
\hline $1^{\text {st }}$ group & $10 \%$ Egg-CaO & $\begin{array}{c}\text { Aluminum hydroxide } \\
\text { gel }\end{array}$ & 3.00 \\
\cline { 1 - 2 } $2^{\text {nd }}$ group & $\begin{array}{c}\text { Binary Ethylenimine } \\
\text { (BEI }\end{array}$ & & 2.4 \\
\hline
\end{tabular}

Group-1: vaccinated with inactivated rabies virus vaccine with $10 \%$ Egg-CaO

Group-2: vaccinated with inactivated rabies virus vaccine with BEI

NB: The antigenic value (AV) of the vaccine must not be less than 0.3

Table 5. Titers of rabies serum neutralizing antibodies in sera of vaccinated dogs

\begin{tabular}{|c|c|c|c|c|c|c|c|}
\hline \multirow{2}{*}{$\begin{array}{c}\text { Animal } \\
\text { Groups }\end{array}$} & \multicolumn{6}{|c|}{ Rabies serum neutralizing antibody titer $/$ weeks post-vaccination } \\
\cline { 2 - 8 } & OWPV & 1 WPV & 2WPV & 4WPV & 8 WPV & 12 WPV & 16 WPV \\
\hline 1 & 0.00 & 16 & 32 & 64 & 64 & 128 & 128 \\
\hline 2 & 0.00 & 8 & 16 & 32 & 32 & 64 & 128 \\
\hline 3 & 0.00 & 0.00 & 0.00 & 0.00 & 0.00 & 0.00 & 0.00 \\
\hline
\end{tabular}

Group-1: was vaccinated with inactivated rabies virus vaccine with $10 \%$ Egg-CaO.

Group-2: was vaccinated with inactivated rabies virus vaccine with BEI.

Group-3: unvaccinated animal as control.

-WPV $=$ week post-vaccination. Antibody titer ${ }^{\circ}=$ the reciprocal of the final serum dilution which neutralized and inhibited the CPE of $100 \mathrm{TCID}_{50}$ of rabies virus.

N.B: The protective level of rabies antibody titer not less than (32).

Rabies remains a very important public health problem in Egypt and vaccination is believed to be the most efficacious and valuable tool in the disease control. Different chemical and physical agents have been used to inactivate rabies virus for vaccine production as beta-propiolactone $(20,21 \& 22)$, and binary ethylenimine (8) are the most widely used for this purpose. It is suggested that it is necessary to develop the calcination method to change the egg shell which is industrial waste, into a valuable 'Egg-CaO. The conversion of raw chicken eggshells which consist of mainly calcium carbonate $\left(\mathrm{CaCO}_{3}\right)$ to calcium oxide $(\mathrm{CaO})$ depends on the thermal treatment. The 
calcium carbonate $(\mathrm{CaCO} 3)$ has been converted into calcium oxide $(\mathrm{CaO})$ at decomposition temperature of $900^{\circ} \mathrm{C}$ for 1 hour is approximately $97.92 \% \mathrm{w} / \mathrm{w}$ (12).

The experimental work showed that X-ray diffraction spectra of the samples were obtained with a $2 \theta$ scan range of $4^{\circ}-80^{\circ}$. The XRD peaks of the calcined chicken eggshells can be seen at 2 e equal to 32.328 (175), 37.481 (471), 54.019 (195), 64.308 (57.8) and 67.536 (52.8) (23), as shown in Table (1) \& Figure (1). The safety test of egg-CaO powder was performed in BHK-cells which did not show cytopathic effect (CPE) confirming complete virus inactivation and when inoculated into mice and puppies, no any abnormal clinical signs were determined is in agreement with (24). It was found that neutralization of the $\mathrm{pH}$ of $\mathrm{CaO}$ solutions with $1 \mathrm{M}$ HEPES did not result in virus titer reduction in comparison with the positive control. It was found that titration of the neutralized samples in BHK-cells showed that egg- $\mathrm{CaO}$ shell solutions at pH $12.3 \mathrm{did}$ not inactivate avian influenza (AIV) strain (H7N1), however, at pH 13.0 it did. Therefore, aqueous solution above $\mathrm{pH} 12.5$ seems to be able to inactivate the influenza viruses (13). Thus, the $\mathrm{pH}$ got 12.3, bringing about the disappearance of disinfection effect of rabies virus (10). The virucidal effects of $3 \%, 5 \%$ and $10 \%$ egg-CaO solutions against rabies virus are summarized in Table (2) \& Figure (2), as rabies virus was inactivated within 45, 30 and 15 minutes incubation, respectively. In this study, Egg-CaO was successfully used to inactivate rabies virus. Table (3) \& Figure (3), illustrated that the complete inactivation process of rabies virus using BEI of $0.001,0.002$ and $0.003 \mathrm{M}$ concentrations at $37^{\circ} \mathrm{C}$ were obtained after 7,5 and 3 hours, respectively. The obtained results revealed that $0.003 \mathrm{M}$ concentration of $\mathrm{BEI}$ inactivated rabies virus within 3 hours of exposure and reduction factor (RF) about $>3.5$. Thus this indicates that inactivation of virus was considered to be satisfied when RF was $\geq 3$ (13), without affecting its antigenicity or immunogenicity, similar findings were stated before (25).

The obtained results of NIH test (table, 4) revealed that rabies vaccine with $10 \% \mathrm{Egg}-\mathrm{CaO}$ had the highest antigenic value adjuvant with aluminum hydroxide gel (3.00) in (12). The rabies vaccine inactivated with binary ethyleneimine had an antigenic value of 2.4 (17).

The demonstrated results in table (5) showed that vaccination of dogs with the prepared inactivated rabies vaccine formulae evoked different levels of specific rabies antibodies as measured by SNT. The protective level of neutralizing antibody titers against rabies virus was (32) as reported by (26). The level of rabies serum neutralizing antibody titers in group-1 (received $\mathrm{CaO}$ vaccine) were higher than that group -2 (BEI vaccine) during the first 4 weeks after vaccination as 64 and 32, respectively and remained at good levels till the end of experiment.

Depending on the obtained results it could be concluded that, the calcinated eggshell (Egg-CaO)-inactivated rabies virus proved to be safe, potent and effective and could be preferable than the same virus inactivated with BEI avoiding the possible public health hazard. Thus, it could be recommended to using Egg-CaO as inactivating agent 
for rabies virus vaccine saving time and costs of inactivation process and at the same time its safety and potency.

\section{REFERENCES}

1. Dietzschold B., Schenell M. and Koprowski H. 2005. Pathogenesis of rabies. Curr. Top. MicrobiolImmunol., 292:45-56.

2. Meslin F.X., Fishbein D.B. and Matter H.C. 1994. Rationale and prospects for rabies elimination in developing countries. Curr Top Microbiol. Immunol, 187:1-26.

3. Dreesen, D.W. 1997. A global review of rabies vaccines for human use.Vaccine, 15:52-6.

4. Hu, R.L., Fooks A.R., Zhang, S.F., Liu Y. and Zhang. F. 2008. Inferior rabies vaccine quality and immunization coverage in dogs (canisfamiliaris) in China. Epidemiol. Infect., 136(11):1556-63.

5. Cleaveland. S, Kaare. M., Tiringa. P., Mlengeya. T. and Barrat, J. 2003. A dog rabies vaccination campaign in rural Africa : impact on the incidence of dog rabies and human dog-bite injuries. Vaccine, 21(17-18):1965-73.

6. Davlin S. L. and Vonville H. M. 2012. Canine rabies vaccination and domestic dog population characteristics in the developing world. A systematic review, 30 (24):3492-502.

7. Nietert W, Kellicut $L$ and Kubinski, H. 1974. DNA protein complexesproduced by a carcinogen, B-Propiolactone. Cancer Res., 34:859-61.

8. Bahnemann, H.G.1990. Inactivation of viral antigens for vaccine preparation with particular reference to the application of binary ethylenimine. Vaccine, 8(4):299303.

9. Tsujimura, M., Thammakarn, C., Yamada, Y., Satoh, K., Hasegawa, T., Ruenphet, S. and Takehara, K. 2012. Antiviral activityof scallop-shell powder against avian influenza virus and gooseparvovirus. Trans. Mater. Res. Soc. Jpn., 37: 567-570

10. Okubo, Y. and Tojyo, H. 2009. Evaluation of slaked lime for Trapping disinfection effect on bacteria and avian influenza virus. J. Jpn. Soci. Poult. Dis., 45:

11. Pie-Yi,W. 2004. Methods of producing eggshell powder.http://www.wipo.int/pctdp/images/patentscope/41/0b/b/000b.pdf

12. Wei, Z; Xu,C and Li, Biores, B. 2009. Application of waste eggshell as low-cost solid catalyst for biodiesel production. Tech., 100: 2883

13. Thammakarn, C., Tsujimura, M., Satoh, K., Hasegawa, T ،.Tamura, M., Kawamura, A., Ishida, Y., Suguro, A., Hakim, H ‘. Ruenphet, S. and Takehara, K. 2015. Efficacy of scallop shell Powders and slaked lime for inactivating avian influenza virus under harsh conditions. Arch. Virol., 160: 2577-2581.

14. Correia, L. M; Saboya, R.M; CampeloNde, S; Cecilia, J. A; Rodríguez-Castellón, E; Cavalcante C.L Jr; and Vieira, R.S. 2014. Characterization of calcium oxide catalysts from natural sources and their application in the transesterification of sunflower oil.Bioresour Technol., 151:207-13. 
15. Rivera, E. Hu, S and Conlha, C. 2013. Ginseng and aluminum hydroxide act as vaccine adjuvants. Vaccine, 21 (11-12): 1149-57. J. Chem. 13/2 176.

16. Ederies, S. M. 1995. Preparation of inactivated tissue culture rabies vaccine. Ph.D. Thesis, Fac. Vet. Med., Cairo Univ.(Virology).

17. Seligmann, B. 1973. The NIH test for potency. Laboratory Techniques in rabies $3^{\text {rd }}$ Ed. WHO monograph series, (23) chapter 33:279.

18. Rossiter,P.B.; Jessett,D.M. and Taylor,W.P. 1985. Microneutralization system for use with different strains of peste des petits ruminant's virus Top. Anim. Hlth. Prod., 17 (2):75-81.

19. Singh, K.V.; Osman, O.A.; Thanan, I. Baz and Ivon EL-Cicy. 1967. The use of tissue culture rinderpest vaccine for Egyptian cattle and water buffalo. Cornell, Vet. J; 7:765-779

20. Gledel, J., B. Mered, and Sureau, P. 1968. Vaccins antirabiques inactives par la beta-propiolactone prepares a partir de cerveaux de chevreauet de cerveaux de souriceau nouveau-ne. Arch. Inst. Pasteur Alger., 46: 76-89.

21. Peck, F. B., Powell H. M., and Culbertson C. G. 1955. A new antirabies vaccine for human use. Clinical and laboratory results using rabies vaccine made from embryonated duck eggs. J. Lab. Clin. Med., 45:679-683.

22. Petermann, H. G., Lang, R., Branche, R. Soulebot, J. P and Mackowiak. C. 1967. Realization d'un nouveau vaccinrabique a partir de culture cellulaire. C. R.Acad. Sci., 265:2143-2144

23. Lesbani, P. Tambah, R. Mohadi and F. Riyanti. 2013. Indo. J. Chem. 13/2: 176.

24. Takehara K., Chinen O., Jahangir A., Miyoshi Y., Ueno Y., Ueda S., Takada Y., Ruenphet S., Mutoh K., Okamura M., and Nakamura M. 2009. Ceramic powder made from chicken feces: anti-viral effects against avian influenzaviruses. Avian Dis. 53: 34-38.

25. Pyke, A.T, Phillips D.A, Chuan, T.F, and Smith, G.A. 2004. Sucrose density gradient centrifugation and cross-flow filtration methods for the production of arbovirus antigens inactivated by binary ethyleneimine. BMC Microbiol., 4(1):3.

26. Sikes, R. K., Cleary, W. F., Koprowski, H., Wiktor, T. J. and Kaplan, M. M. I97I. Effective protection of monkeys against death from street virus by post-exposure administration of tissue-culture rabies vaccine. Bulletin of the World Health Organization 48, I-I 


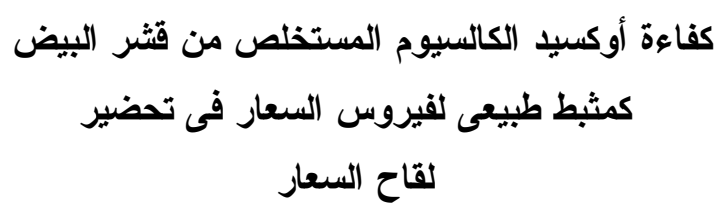

محمد بريك شندى،أكرم فؤاد سليمان، همت سليمان الامام، عطيات محمد قطب

معرة بحوث الامصال و اللقاحات البيطرية - العباسية- القاهرة- ص ب:ا | |

هذه الدر اسة تهدف الى تطوير و انتاج لقاح السعار وذلك بأستخدام مادة أوكسيد الكالسيوم

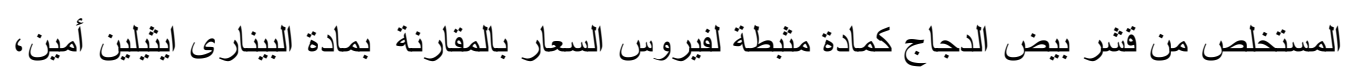

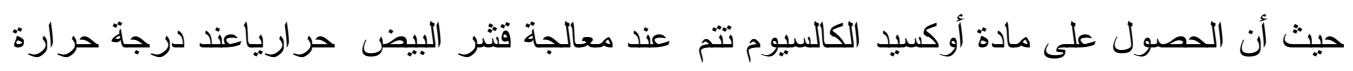

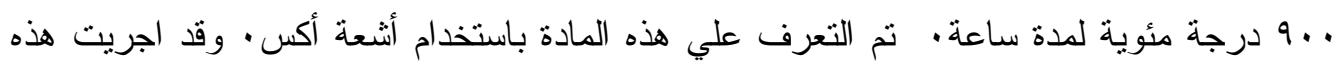

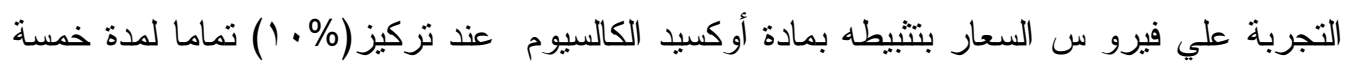

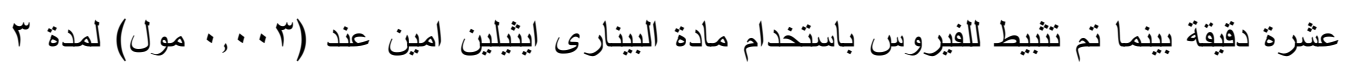

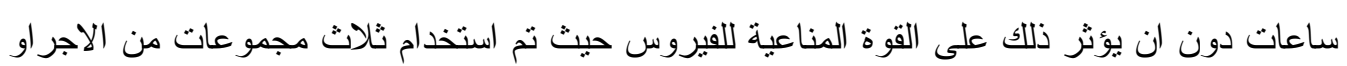

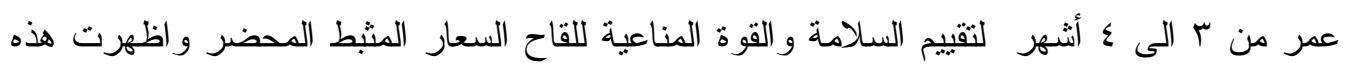
النتائج انه لا يوجد أى بقايا معدية للفيروس وذلك عند استخدام لقاح السعار المثنط بمادة أوكسيد

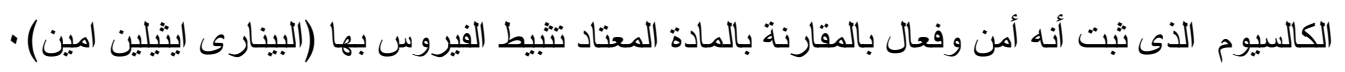
و هكذا فإن طريقة التثبط البديلة بمادة أوكسيد الكالسيوم قادرة على الحفاظ على بلى سلامة البرونين

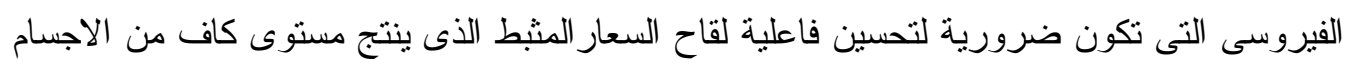

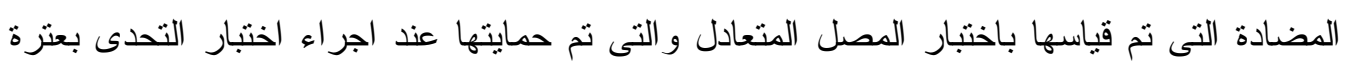

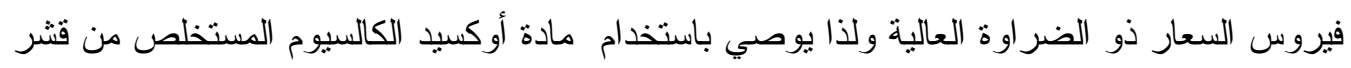
البيض كمادة طبيعيه منبطة لفيروس السعارو التى تؤدى الى توفير الوقت و التكلفة اللازمة لعملية 